\title{
産業技術政策の技術基盤化について 一食品・バイオ産業を視野に入れて一
}

\author{
並 河 良一 \\ 名古屋大学大学院経済学研究科 教授
}

1.はじめに

日本食品工学会は食品をマクロな立場から総合的・シス テム的に捉えることを特徵とする。この考え方は必然的に， 自然科学の周辺領域のみならず社会科学との融合に至るで あろう。したがって産業技術を社会科学の視点から記述す る本稿は，同会の対象分野の境界領域に位置しており，会 員諸氏特に各種研究機関における研究管理者の参考になる と考える.

近年，産業技術政策を取り巻く経済・社会環境は大きく 変化している. たとえば技術のソフト化・業際技術の進歩 など技術の質的変化，新産業の勃興など産業構造の変化， 旧来型業界の役割の低下に伴う行政と産業の関係の変化， 経済のグローバル化の進展である．また省庁の再編，規制 緩和, 各種基本法の制定・改訂（科学技術基本法；1995 年, 食糧農業農村基本法; 1999 年, 中小企業基本法; 1999 年）など産業技術政策に関係する基本フレームが変 更されている，産業技術政策もこれらの変化に対応し，基 本政策のあり方を検討する時期が近いと考える．基本政策 の変更は, 既存の基本政策とは異なる新たな政策の方向を 示すものであるが，既存政策の否定・発展いずれの場合に おいても，それまでの政策の実務的な修正・調整の集積す なわち政策の変遷がどのような方向性を有していたかを把 握することが重要である。

本稿では，近年（最近約 30 年間，以下同じ）の個別産 業技術政策（工業標準制度，工業所有権制度，研究開発 プロジェクト，国立研究機関，中小企業技術政策および地 域技術政策）を概観し，産業技術政策の変遷の方向性を把 握する，政策の変遷は，政策理念，政策主体，政策目標， 政策対象，政策手法など多岐に及ぶが，本稿は政策手法に 焦点を当てて検討する.

なお，大学等で研究される基礎技術と応用技術を中心と する産業技術では，これを扱う政策理念に差異があり，ま た同じ産業技術でも先端技術と現場技術では，その政策手 法等に差異があるため, これらを同列に論じることはでき ない. 本稿は産業技術のうち比較的高度の応用技術を念頭 において検討する.

検討対象として主に「工業系」の産業技術政策をとりあ げるが，その理由は，工業技術は産業技術の中核にあり， 一つの省（通商産業省）で所管されており体系的に把握し やすいからである．食品・バイオ技術は工業系と農林系の 狭間にあり，また食品は農林水産省に所管されているが，
その産業技術政策の大きな流れは他技術と異ならない，食 品・バイオ技術については, 工業系技術の記述の中で適宜 言及する。

\section{2. 検討の視点一技術開発と技術基盤}

一国の産業の技術力は技術開発力だけで決まるのではな く，経済・社会とも深い関係を有する。このため産業技術 政策は技術開発力だけでなく, 経済・社会も視野に入れた 総合的な構造を有する. 具体的には産業技術政策は, 国自 らが技術開発を行うあるいは産業の技術開発を支㩖するこ とにより産業の技術革新を促進する手法（以下本稿では 「技術開発」と記す）と，産業の技術革新を支える制度や 基盤（同「技術基盤」）を整備する手法に区分できる.

「技術開発」系の政策は技術そのものに着目し，技術に 直接作用する手法である。「技術基盤」系の政策は技術の 背景にある経済・社会に着目し，技術には間接的に作用す る手法である。一般に「技術開発」系の政策は技術につい て国の主導性ないし関与を前提とするが，「技術基盤」系 の政策は産業の主導性を前提とし，国は競争条件の整備， データベースの構築など補助的, 後見的な役割にとどまる. 両者は政策手法としての性格は異なるが，相互補完的な関 係にあり，多くの産業技術政策は両方の要素を含む. 研究 開発プロジェクトは「技術開発」要素の強い政策であり， 工業所有権制度は「技術基盤」要素の強い政策である. 通 商産業省も産業技術政策を「研究開発」と「基盤整備」に 区分しているが[1]，これらを単に政策を分類する名称と とらえ，個別政策を構成する要素とは考えていない.

以下では,「技術開発」と「技術基盤」の両要素を指標 として, 主要産業技術政策の変罳を検討する.

\section{3. 個別産業技術政策の变覆}

\section{(1) 工業標準制度}

近年の工業標準制度の変罦を通観し，同制度の「技術基 盤」としての性格が強まっていることを示す.工業標準制 度（日本工業規格；JIS）は, 工業標準化法によれば, 経 済・社会活動の利便性を確保するために，工業製品の形 状・法・品質 - 性能, 生産方法 - 使用方法, 試験方 法・測定方法, 用語・単位等を一定の規格に統一する制度 である。この定義が示すように，もともと工業標準制度は 「生産技術」の基盤となる制度ではあるが, 技術革新の促 
進を目的とする制度ではなかった。しかし近年，制度を取 り巻く経済・社会の変化に対応し，工業標準制度の機能や 考え方が大きく変化している，以下では，工業標準制度の 変遷を，技術革新，企業間競争，国際標準の三つの側面か ら，「技術基盤」要素に焦点を当てて検証する。なお加工 食品等の規格を定める日本農林規格（JAS 規格）について も若干付言する。

(1) 技術革新と工業標準制度

技術革新が進む中で，工業標準制度は技術革新を促進す る「技術基盤」政策に変わりつつある.

工業標準制度は高度成長期には品質管理・生産効率を支 える制度として重要な役割を果してきた，高度成長の終焉 後, 産業が規模の追求から高付加価值・多様性の重視に転 換する中で, 工業標準制度は，技術の多様性や急速な変化 と矛盾背反する要素を内包すると考えられ[2]，沈帯期に 入る。しかし産業技術の高度化が急速に進む 1980 年代に なり，技術革新を促進する多様な政策手段が模索される中 で，工業標準制度が技術革新を促進する機能を有すること が認識されてきた。 1985 年に制定された第 6 次工業標準 化長期計画は工業標準制度について, 従来からの産業基盤 としての役割に加え, 今後は技術革新を支援する「技術基 盤」としての役割が重要になる旨述べている，平野も 1988 年に, 高度技術化時代の標準化は開発段階で先行的に実施 することが強く要請され, 開発と標準化の融合化・一体化 が進むであろうと述べている[2]. 日本規格協会も今後の 標準化の方向として，企業においては「開発段階からの標 準化」，国や業界団体においては「技術開発を支援する標 準化」が重要と述べている[3]．このように工業標準制度 は，技術革新を促進する「技術基盤」として期待されるよ うになってきた。

工業標準制度に関連し, 標準管理に言及する。標準管理 とは, 計量標準 (キログラム原器等) や標準物質など産業 活動を支える標準を管理する事業であり，政府機関の業務 である，近年，標準管理に技術革新を促進する機能が期待 されるようになり, 研究活動の基礎となる物性・化学物質 の安全性等のデータベースや有用微生物等の管理・保存が 標準管理に含まれている。さらに最近は既存データを収 集・管理するだけでなく, 実験・研究を行い新規データを 獲得すること, たとえば遺伝子やタンパク質の解析も標準 管理の中に含まれている。このように標準管理の概念は発 展拡大し, 現在では技術革新を促進する「技術基盤」と なっている.

(2) 企業間の技術革新競争と工業標準制度.

企業間の技術革新競争が激化する中で, 工業標準制度は 企業間の競争条件を整備する「技術基盤」の機能を有する ようになってきた。

1960 年代までの工業標準化は，市場化された成熟技術 を対象とするケースが大半であり, 工業標準制度と企業間 競争の関係は希薄であった. 企業間の技術革新競争と標準 化の関係が認識される契機となったのは，1970年代の家 庭用ビデオの標準化問題である.まず 1975 年にソニーが ベータマックス方式ビデオを，1976 年に日本ビクターが
VHS 方式ビデオを発売し, 家電業界内に両規格の主導権 争いが生じた，激しい主導権争いのため規格化（JIS 化） は進まず，市場の大勢が決した 1987 年になり，ようやく 規格化された（1988 年にソニーが VHS 方式ビデオの発売 に踏みきった)。この事例は, 標準化が企業間競争と深い 関連を有すること, 標準化の遅れは研究投資, 生産・販売 投資の無駄を生じさせること，したがって標準化は研究段 階から行う必要があること, 換言すれば研究段階からの標 準化は技術革新の促進に役立つことを示唆している. 最近 では記録媒体デイスクの DVD の標準化をめぐり企業間競 争が行われている[4]. このように企業間の技術革新競争 の中で，工業標準制度は技術革新を支える「技術基盤」の 機能を有することが認識されるようになっている.

(3) 工業標準の国際化

国際標準化の面でも，工業標準制度と技術革新の関係が 深化しており，工業標準制度の「技術基盤」としての機能 が拡大している.

工業標準の国際化は 1963 年の第 2 次工業標準化長期計 画以降, 毎次の長期計画で, 重要課題と位置づけられてき た[4]. 1980 年に合意された GATT スタンダード・コード は, 強制法規分野の規格・基準認証制度に関する規律を定 めており，関連する工業標準の国際化が積極的に進められ てきた。しかし国際標準化は十分に進まず，通商産業省の 「工業標準化推進長期計画の策定に関する建議」(1990 年) は，それまでの標準化を「国内規格中心主義」であったと 評価している，次いで 1995 年にWTO（世界貿易機関）体 制の発足, TBT（貿易の技術的障害協定）の発効に伴い, 国家規格はISO（国際標準機関）等の国際規格を基礎とす ることとされた。 これにより工業標準の性格は大きく変化 し，原則として国内標準と国際標準の整合性が求められる こととなった。このため国際標準となった技術は市場で優 位な立場を確保できることとなり，1997 年の工業標準調 査会国際部会答申は「標準を制する者はマーケットを制す る」と述べている。このため, 企業は国際標準を目指した 技術革新を行うこと, 国は, 我が国産業の国際的優位性を 確保するため，国際標準のイニシアチブをとるべく共通基 盤的な研究を行うことがそれぞれ求められることとなった。 国はこのような共通基盤的な研究として, 免疫化学的な化 学物質の計測法, 自動車のリサイクル率算定方法等の研究 を進めている.

(4) 日本農林規格 (JAS 規格)

なお，JAS 規格は消費者保護の傾向の強い制度であり， 規格と技術革新・企業間競争の関係は，JIS 規格の場合ほ ど強く認識されてこなかった. 1998 年の農林物資規格調 査基本問題委員会の報告も，新製品や新技術の開発にJAS 規格の改正が追いついていないと述べている．またJAS 規 格も ISO や CODEX 等の国際規格との整合性を求められ ているが，技術革新との関係が希薄なため，国際技術戦略 としての位置付けは不明確である。しかし 1995 年以降運 用されている，熟成八ムや有機農産物加工食品のように特 別な生産方法や原材料に着目した規格（特定 JAS 規格制 度）は，新技術の方向を律する要素を含んでおり，将来に 
おいて JAS 規格と技術革新の関係が顕在化する可能性が ある。

\section{(2) 工業所有権制度}

工業所有権のうち主に特許について，その変遷を検証し， 「技術基盤」としての機能が拡大していることを示す，特 許法は制度の目的を，「発明の保護及び利用を図ることに より，発明を奖励し，もって産業の発達に寄与すること (特許法第 1 条)」と規定している. すなわち特許制度の政 策目的は，第一に，発明者に独占的使用権を与えることに より発明を促進すること，第二に，発明の内容を公開し， 重複投資を防止するとともに第三者の発明を促進すること である．前者は発明者のさらなる発明，後者は発明者以外 の発明を促進するものである。このように特許制度は，技 術革新（発明）を促進する制度である。この目的を達成す るために特許法は発明者と第三者の関係を規定している. 発明者に対し発明の独占的使用権を与えるが発明の内容を 公開する義務を課し，第三者に対しては発明を利用する機 会を与えるが，発明を使用・模倣をしない義務を課してい る.このように特許制度は，研究に対し資金的な支援をす ることなく，発明者と第三者の法的な関係を規定すること により技術革新を促進する制度である。この意味で特許制 度は典型的な「技術基盤」である．以下では近年の特許制 度の変䍘を，特許等の保護対象技術，特許の制度・手続き の順で検討し，「技術基盤」との関係を把握する。 また特 許制度に関連し，未利用特許の流通促進にも言及する。近 年の工業所有権制度の変遷では, バイオ技術が議論の中心 の一つとなっている.

\section{(1) 特許等の保護対象技術の拡大と技術基盤}

特許等で保護される技術の範囲は, 化学・生物系技術と ソフトゥエア系技術で急速に拡大している。 まず化学・生 物系技術については，1975 年に物質特許制度が導入され， それまで製法特許だけが認められていた化学物質，医薬， 飲食物・嗜好物そのものに特許が認められた，植物新品種 も 1975 年以降は特許審査の対象となり (審査基準の公表), また 1978 年には種苗法が制定され，特許要件を満たさな い植物新品種にも工業所有権が付与されることとなった。 微生物自体は 1979 年, 動物新品種は 1993 年の審査基準 の公表以降，実務的な課題は残るものの，特許対象とされ ている $[5,6]$. 現在は遺伝子の特許権について，日米欧の 審査要件の整合性を図る努力と並行して，実務的な検討が 進みつつある. 次にソフトゥエア系技術については，コン ピュータ・プログラムが 1975 年以降は特許審査の対象と なり (審査基準の公表)，1985 年以降は著作権法において も保護されている。 また半導体集積回路の回路配置が 1985 年の新規立法により保護の対象となった。現在は電子商取 引，デリバティブなどのビジネス関連特許の本格的導入に 向けて実務的な検討が進められている。このように特許等 で保護される技術の範囲が拡大しており，より多くの分野 で特許等が技術革新を促進している，すなわち技術革新に おいて, 特許という「技術基盤」の果たす役割が拡大して いる.
(2) 特許の制度・手続きの変遷と技術基盤

近年，特許制度特にバイオ分野の特許の中に，新たな考 え方が見出せる，従来特許によって保護されるものは研究 者の「知的」生産物であると考えられてきたが，「投資」 の生産物の保護という考方方が生じつつある。平井は，バ イオ関連特許に関する考察から, 近時の発明は膨大な人 的・物的資源を必要とすると認識し，産業政策上保護に値 する相当量の「知的労働」および「経済資源」の産物を特 許法の保護対象とすべきと述べている[7]。平嶋は，米国 の判例を分析し, 天然に存在する遺伝子を特許法で保護す る意義は，開発投資の保護にあると述べている[8]，彼ら は，特許が保護する技術的成果の背景にある投資という企 業経営的な要素を意識している．既述のとおり「技術基盤」 系の政策は技術の背景にある経済・社会に着目する手法で あり，特許制度は研究投資を視野に入れることにより， 「技術基盤」としての性格を強めている。

特許手続きについてもその変遷の中に「技術基盤」 的な要素が強くなる傾向が見られる。1970 年には出願の 早期公開制度が導入され，特許制度のデータベースとして の機能が向上し，研究投資の重複を減少できることとなっ た. 1994 年には特許付与後の異議申立て制度が導入され， 迅速な特許権付与が可能になり，研究開発に対する投資意 欲を向上させることとなった。

(3) 未利用特許の流通

近年，我が国の保有特許約 90 万件のうち約 60 万件を占 める未利用特許の活用が重要な政策課題と認識されてい る. たとえば特許庁は, 特許流通市場の整備, 知的財産取 引事業者の有成等の施策に加え，手続き代理中心の弁理士 業務を特許流通サービスまで拡大する方針を示している. 1999 年の工業所有権審議会の答申も，知的財産市場の整 備，知的財産専門サービスの充実等を強調しており，特許 の流通促進がさらに加速されるものと考えられる。このよ うな政策動向は膨大な未利用特許の存在そのものが，技術 革新を促進する「技術基盤」として評価されるようになっ たことを示している.

\section{(3) 研究開発プロジェクトと産業への研究貫の供給}

大型の研究開発プロジェクトは，産業界への研究費の供 給，共同研究等を通して，我が国産業の技術力の向上に寄 与してきた。研究開発プロジェクトは典型的な「技術開発」 であるが，近年，多様なプロジェクトが創設される過程で， 「技術基盤」の要素が見られるようになってきた。 以下，近 年の主な研究開発プロジェクトの中の「技術基盤」的要素 を, プロジェクト形態，産業への研究費供給形態等を通し て検討する。

1970 年代の研究開発プロジェクトは, 大型工業技術研 究開発制度（大プロ）に代表される，大プロは，国が産業 政策上必要なテーマを選定し，企業，技術研究組合等に研 究開発を委託（補助）する方式をとっている。その後，新 エネルギー技術（サンシャイン計画），省エネルギー技術 (ムーンライト計画)，次世代技術等についても，同様の研 究開発プロジェクトが創設された。これらはいずれも研究 
費を産業界に供給する仕組みであり，典型的な「技術開発」 系の政策である.

1980 年代半ばから, ファインセラミックス, 超伝導, 地 球環境など産業政策上重要な研究開発を行う公益法人形態 の専門的研究機関の創設が相次いだ．研究機関が産業界か らも研究を受託しうるという点では「技術基盤」の要素も あるが，研究費の大半を政府に依存するため「技術開発」 の色彩が強い政策である.

1985 年の基盤技術研究円滑化法の制定は, 研究開発プ ロジェクトの転換点である．同法に基づき設立された基盤 技術研究促進センターは，研究専門企業（バイオ系では， 蛋白工学研究所等）に対し資本金の最大 $70 \%$ まで出資し て, 先端技術の研究開発を実施させる. 従来の大プロ等で は，産業界に交付した研究費の回収は念頭になかったが， 同制度は，研究専門企業が研究成果（特許等）の実施権を 設定して得る利益からの配当を予定している．同制度は大 型の研究開発を企業に実施させ, 出資者として研究開発を 促進するもので，市場経済システムを用いて研究開発を促 進する制度である．同制度は研究開発に企業性・経済性を 導入した点で画期的である（現実には利益・配当はほとん どなかった)，本制度も産業界に研究費を供給する点では 「技術開発」の要素が強いが，技術の背後にある企業経営 や経済に着目した点では「技術基盤」政策の要素が見出 せる.

なお農林・食品分野等でも同様の制度が整備された（生 物系特定産業技術研究推進機構 (生研機構) 法等).

1989 年に創設された研究基盤整備事業は，研究開発に 必要な大型の施設・設備を整備し企業・研究者等の共用に 供する制度であり，典型的な「技術基盤」系の政策である (バイオ系では，鉱工業海洋生物利用技術研究センターが 設置された)。

1990 年代には起業ブームを背景に，基盤技術研究促進 センターの研究開発型企業出資制度など研究開発型ベンチ ヤ一企業への出資制度が数多く設けられている. その多く は研究資金を供する仕組みであるが，我が国の技術力の向 上を直接の目的とせず，起業活動の支援に主眼がある。こ のため出資者として主に主張するのは研究内容や技術的な 研究成果ではなく, 経済的に評価された研究成果である. このためべンチャー企業への出資制度の多くは「技術開発」 の要素もあるが, 「技術基盤」の要素が濃厚な政策である. なお, 農林・食品分野では, 2000 年から生研機構が新事 業創出研究開発事業を開始する.

このように典型的「技術開発」政策である研究開発プロ ジェクトも「技術基盤」の性格を帯びつつある.

\section{（4）国立研究機関}

国立研究機関の本来の機能は「技術開発」にある. 国立 研究機関は産業構造の変化に対応し, 組織改編を重ねてき たが，その主たる目的は「技術開発」機能の向上にあった。 しかし国立研究機関に係る制度改正等の中に，「技術基盤」 の要素が見られる，以下，国立研究機関をめぐる近年の主 要な動きである, つくばへの移転, 職務発明制度, 独立行
政法人化の中から「技術基盤」の要素を抽出する.

第一は，つくばへの移転である。1970 年に筑波研究学 園都市建設法が制定され, 多数の国立研究機関がつくばに 移転した. 現在つくばには国立大学も含め 46 の公的研究 機関および多数の民間研究所が立地し, 同地に研究機能の 大集積が形成された。研究機能の集積は, 単に研究機関が 同じ地に立地していることにとどまらず, 研究機関・研究 者の相互作用を通じて, 高度の研究を生み出す土䁃となっ ている.このため研究機能の集積が, 他の研究機関を誘引 し, 集積効果が相乗的に向上する. 中島は, 学術研究機関 の集積地には優れた研究者が集まる (中略) 研究所の集積 利益がますます研究所をひきつける旨述べている[9]. 国土 庁は, 研究機関の集積のメリットとして研究者の交流機会 や生きた情報などの知的刺激, 共同研究や施設利用の容易 さ，研究支援サービス機能等をあげている[10].このよう に研究機能の集積は研究を促進する機能を有しており，つ くばへの移転は, 研究機能の集積という「技術基盤」を形 成する政策として評価される。

第二は, 職務発明制度である. 従来, 国立研究機関研究 者の職務上の発明は，少額の職務発明補償金の支払により 国に帰属するのが事実上の原則となっていた．1996 年の 科学技術基本計画は，国立研究機関の研究者個人への特許 権等の帰属制度を導入べき旨指摘した $(2$ 章 $\mathrm{V}(2))$. この 指摘に基づき通商産業省，科学技術朾，農林水産省等は職 務発明規定を改正し，特許権等を国と研究者が $50 \%$ ずつ 持ち合うことが可能になった。これ以降，研究者個人によ る研究成果の利用に道が開かれ，研究者の研究意欲の向上， 産業界のニーズに合った研究の促進が図られることとなっ た.この意味で特許権等の研究者帰属制度も「技術基盤」 としての性格を有する. 科学技術基本計画も指摘している ように, 今後研究者の流動化が進めば, 特許権等の研究者 帰属制度は研究者にとってさらに強いインセンティブにな ると考えられる，農林水産省金下の研究機関の中では，産 業との接点の多い食品総合研究所において, 同制度は有効 であろう.

第三は, 国立研究機関の独立行政法人化である. 1999 年 7 月に独立行政法人通則法が, 同 12 月に個々の独立行 政法人設置法が公布され，国立研究機関の独立行政法人化 が進められている．独立行政法人化された国立研究機関の 重要な機能の一つに産業界からの研究受託がある。

研究受託は, 国立研究機関の高い技術力を直接産業界に 移転する有効な方法であり，1990 年の科学技術行政に関 する行政監察もその必要性を指摘している。しかし従来は, 総予算主義により歳入歳出はすべて予算に編入する必要性 があること（財政法第 14 条），官民癒着を防止する閣議決 定 (1948 年 1 月 30 日) 等の障害があり産業界からの研究 受託は不活発で, 共同研究や企業からの研究員受入等の便 法がとられていた。通則法，設置法（独立行政法人産業技 術総合研究所法, 独立行政法人食品総合研究所法等) と も研究受託には直接言及していないが，1999 年 1 月の中 央省庁等の改革に係る大綱は, 独立行政法人の研究受託を 前提としており（V.4.(4) (6)イ）, 独立行政法人化により研 
究受託が制度として確立することとなる。

産業界からの研究受託により，国立研究機関は経済・社 会のニーズに合った研究を実施することとなる、産業界か らの研究受託は, 独立行政法人に研究サービス産業の性格 を付与するもので, 経済・社会の発展に寄与する（通則法 第 1 条）直接的な仕組みである. したがって産業界からの 研究受託は, 産業界の技術力を支える「技術基盤」として の機能を有し, 独立行政法人化は「技術基盤」系の政策と 言える。

\section{（5）中小企業技術政策および地域技術政策}

中小企業技術政策は，その時々の経済情勢に対応した多 様でキメ細かい助成措置と地域公設試験研究機関（公設 試）の研究・技術指導を中心に構成されており，「技術開 発」の傾向が強い政策である. しかし近年，中小企業技術 政策にも「技術基盤」の要素が見られる。

1980 年代後半に大ブームになった異業種交流は，厳密 には技術政策ではないが，多くの業際的技術を産み出して いる，異業種交流は，研究費の供給を目的とせず，単に異 業種の中小企業経営者等に交流の機会を提供する制度であ る. しかし交流の結果として新分野への進出, 業際的新技 術の創造を促進するもので，「技術基盤」としての機能を 有している。1992 年には特定中小企業集積活性化法 （1997 年以降，地域産業集積活性化法）が制定された。同 制度は従来型の指定地域への助成が中心であり「技術開発」 の傾向の強い政策であるが, 中小企業集積の新産業創出機 能に着目しており，「技術基盤」整備の考え方も見られる.

1999 年に改正された中小企業基本法は, 独立した中小 企業の自主的な努力を助長すること（第 3 条）を政策理念 とする. そして中小企業像を, 従来の画一的な「保護」す べき「弱者」から，「活用」すべき「経済のダイナミズム の源泉」へと転換している. そして今後の中小企業政策は, 行政主導から企業主導に移行し，行政は支援メニューを提 示するにとどまるとしている. 技術面では, 中小企業を革 新的技術を創出する担い手ととらえ，具体的には，行政に よる同業組合を通じた指導から意欲のある個別中小企業に 対するコンサルティングという考え方に移行している．今 後，基本法の精神の下で個別政策が立案されていくが，そ の過程で，中小企業技術政策は産業主導の「技術基盤」系 の政策にシフトしていくと考える.

次に地域技術政策である。近年，地域の技術力の向上を 図るために多様な政策が講じられてきた。重要地域技術研 究開発制度等の「技術開発」系の制度も設けられてきたが, 政策の中心は「技術基盤」系の政策である．1980年代に は，地域に技術集積を形成する政策が相次いで講じられて きた. 1983 年にテクノポリス（高度技術工業集積地域開 発法)，1986 年にリサーチコア (民間能力活用法 1 号施設)， 1988 年に頭脳立地（地域産業高度化特定事業集積法）の 各制度が創設された。これらの最終的な目標は地域開発で あるが，その施策内容は地域に研究機関，高等教育機関， 高度技術型産業およびこれらを支援する産業を集積するこ
とにより，地域技術の高度化を図るものであり，典型的な 「技術基盤」系の政策である。

\section{4. ま め}

近年における産業技術政策の変遷の方向を, 主要政策ご とに「技術開発」「技術基盤」の二つの要素を指標として 検討した，工業標準制度は技術革新との関係が希薄であっ たが，近年，「技術基盤」性の強い政策に変質している. 典型的な「技術基盤」である工業所有権制度は，技術革新 に果たす役割がさらに拡大している，研究開発プロジェク 卜，国立研究機関，中小企業技術政策は「技術開発」要 素の強い政策であるが，制度の変遷の中に多くの「技術基 盤」的要素が見出せる．また地域技術政策の多くは技術集 積を促進する「技術基盤」系の政策である。このように近 年の産業技術政策は総じて「技術基盤」の要素が強まりつ つある.

「技術基盤」政策の内容は，産業集積，研究支援産業， 研究情報などの基盤整備から, 研究競争条件の整備, 研究 成果の保護・実用化促進, 重複研究投資の防止など研究投 資環境の整備まで幅広く含んでいる。また，「技術開発」 は，国がリードするのではなく，経済あるいは市場がリー ドする方向に移行している.

本稿は産業技術政策の「技術基盤」化をもたらした要因 については分析しておらず，これは今後の検討課題である. 学際・業際技術分野の拡大, 企業経営の多角化・国際化 により，国が「技術開発」をリードすることが難しくなっ ていること，業界内の主要企業による従来型の「技術開発」 が機能する素地が失われつつあること等が関係している可 能性がある。また綮しい財政事情も背景の一つであろう。

\section{丟考文 献}

1）通商産業省工業技術院，90 年代の産業科学技術ビジョン， 通商産業調查会, 1990, pp.1-7, pp.45-51.

2）平野敏也，工業標準化の変遷と展望，日本規格協会，1988, pp.1-5, pp.152-154.

3）日本規格協会, 産業発展と工業標準化， 1995, pp.43-44, pp.21-23.

4）山田肇，技術競争と世界標準，1999， NTT 出版，pp.73-78.

5）大塚文昭，特許法通鑑，発明協会，1996，pp.12-19.

6) 吉藤幸朔 能谷健一, 特許法概説 (第 13 版), 有斐閣, 1998, pp.146-148.

7) 平井昭光, 保護対象適格要件の再考に関する一試論, 特許研 究, 24, 4-17 (1997).

8）平嶋竜太, 天然に存在する遺伝子の特許法による保護, パテ ント, 49 (5), 89-97 (1996).

9) 中島清, 研究所立地論の体系化に関する考察, 経済地理学年 報，35 (3)，181-199 (1989).

10) 国土庁大都市圈整備局, 研究機関の立地戦略, 大藏省印刷 局, 1993, pp.233-248. 